\title{
Supine PCNL is the Way Forward, with Reduced Anesthesia and Operative Times As Compared to Prone PCNL, Along with Comparable Blood Loss and Stone Free Rates
}

\author{
Supin PCNL ile Karşılaştırııdığında, Supin PCNL, Anestezi ve Operasyon Süreleri Azaltılarak \\ Ileriye Doğru llerliyor
}

\author{
(D) Adnan Siddiq Awan, (D) Salman Khalid, (D) Shariq Anis Khan, (D) Shoaib Mithani, (D) Jahanzeb Shaikh, (D) Imran Sharif \\ The Kidney Centre Postgraduate Training Institute, Department of Urology, Karachi, Pakistan
}

\section{What's known on the subject? and What does the study add?}

Since the advent of prone percutaneous nephrolithotomy (PCNL) in 1976, it is a widely accepted procedure of choice for renal stones $>2$ $\mathrm{cm}$. Supine PCNL has been realized as even better modality than prone PCNL but is still not being performed frequently due to a fear factor of colonic injury. Another factor is that surgeons acquainted with prone PCNL do not want to acquire a new modality with fear of rough transition. Supine PCNL keeps its promise of reduced operative and anesthesia time.

\begin{abstract}
Objective: The aim of this study is to compare safety and efficacy of supine versus prone percutaneous nephrolithotomy (PCNL) in terms of stonefree rate, operative time, anesthesia time and blood loss in a retrospective case-control trial.

Materials and Methods: Fifty patients underwent supine PCNL during the study period (group A). Equal number of patients, who underwent prone PCNL during same period with similar demographic and clinical attributes, were taken as controls (group B). Demographic details, such as gender and age, and body mass index, stone size, stone location and stone laterality were comparable between the two groups. Pre- and post-operative hemoglobin $(\mathrm{Hb})$ levels in patients in both groups were tabulated. Variables analyzed to compare the groups included operative time, anesthesia time, fall in $\mathrm{Hb}$, blood transfusion, stone clearance and need for auxiliary procedure.

Results: The median operative time (minutes) in patients of group A [35; interquartile ratio (IOR): 25], was significantly different from group B (70; IQR: 40) ( $p=0.000)$. The median anesthesia time (minutes) in patients in group A (50; IQR: 25$)$ was significantly different from group B (85; 45) $(p=0.000)$. The median fall in $\mathrm{Hb}(\mathrm{g} / \mathrm{dL})$ in patients in group A (1.700; IQR: 1.2) was significantly different from group B (1.200; IQR: 2.4) ( $p=0.967)$. Two patients in group $A$ and 7 in group B needed blood transfusion $(p=0.080)$. Thirty two patient in group $A$ and 34 in group $B$ achieved stonefree status $(p=0.833)$. Eleven patients in group $A$ and 6 in group B needed auxiliary procedure in the form of extracorporeal shockwave lithotripsy $(p=0.287)$.

Conclusion: Supine PCNL is as safe and effective as conventionally performed prone PCNL, with an added benefit of decreased operative and anesthesia time.
\end{abstract}

Keywords: PCNL, Supine, Prone, Valdivia

Öz

Amaç: Bu çalışmanın amacı retrospektif bir olgu kontrol çalışmasında supin perkütan nefrolitotomi (PCNL) ve pron PCNL'yi taşsızlık oranı, operasyon süresi, anestezi süresi ve kan kaybı bakımından karşılaştırmaktır.

Gereç ve Yöntem: Çalışma süresince 22 hastaya supin PCNL yapıldı (grup A). Aynı dönemde benzer demografik ve klinik özellikleri olan ve pron pozisyonda PCNL uygulanan eşit sayıda hasta kontrol grubu (grup B) olarak çalışmaya dahil edildi. İki grup arasında cinsiyet, yaş, vücut kitle indeksi, taş boyutu, taş yeri ve taş lateralitesi gibi demografik detaylar benzerdi. Her iki gruptaki hastaların ameliyat öncesi ve sonrası hemoglobin (Hb)

Correspondence: Adnan Siddiq Awan MD, The Kidney Centre Postgraduate Training Institute, Department of Urology, Karachi, Pakistan

Phone: +92-21-36683032 E-mail: dradnansiddiq@hotmail.com ORCID-ID: orcid.org/0000-0002-8587-9397

Received: 24.04.2018

Accepted: 04.07.2018

Cite this article as: Awan AS, Khalid S, Khan SA, Mithani S, Shaikh J, Sharif I. Supine PCNL is the Way Forward, with Reduced Anesthesia and Operative Times As Compared to Prone PCNL, Along with Comparable Blood Loss and Stone Free Rates. J Urol Surg 2019;6(1):1-6.

๑Copyright 2019 by the Association of Urological Surgery / Journal of Urological Surgery published by Galenos Publishing House. 
düzeyleri tablolandı. İki grubun karşılaştırılması için analiz edilen değişkenler arasında ameliyat süresi, anestezi süresi, Hb'de düşüş, kan transfüzyonu, taş klirensi ve yardımcı prosedür ihtiyacı sayılabilir.

Bulgular: Grup A'daki hastaların $(35 ; 26)$ operasyon zamanı medyan ve çeyrekler açıklığı (IOR) değerleri grup B'den (87,5; 45) anlamlı olarak farklıydı $(p=0,000)$. Grup A'da anestezi süresi, medyan ve IQR $(35 ; 26)$, grup B'den $(87,5 ; 45)$ anlamlı olarak farklıydı $(p=0,000)$. Grup A'daki $(1,700 ; 1,2)$ Hb'li hastaların Hb'deki fallen medyan ve IQR değerleri grup B'den $(1,400 ; 2,4)$ anlamlı olarak farklıydı $(p=0,613)$. Grup A'da 1 hasta, grup $B^{\prime}$ de 3 hastada kan transfüzyonuna ihtiyaç vardı $(p=0,294)$. Grup A'da 14, grup B'de 15 hastada tam taş açıklığı saptandı $(p=0,500)$. Grup A'da 5 hasta, grup B'de 2 hastada ekstrakorporeal şok dalgası litotripsi şeklinde yardımcı prosedür gerekti $(p=0,206)$.

Sonuç: Supin PCNL, geleneksel olarak yapılan pron PCNL kadar güvenli ve etkilidir, ancak azaltılmış operasyon ve anestezi süresinin ek bir yararı vardır.

Anahtar Kelimeler: PCNL, Supin, Pron, Valdivia

\section{Introduction}

Fernström and Johansson (1) described the first percutaneous nephrolithotomy (PCNL) in 1976 performing it in the prone position and adopting it as a standard surgical procedure for renal stones larger than $2 \mathrm{~cm}$. Prone PCNL became widely popularized and totally replaced open surgery for renal stones and emerged as the gold standard procedure for 2 decades.

In prone PCNL, the patient is initially placed in dorsal lithotomy position to insert ureteric catheter and then the position is changed to prone for the remaining procedure. This results in an unnecessary delay and also harbors risk of damaging nerves, limbs, neck, and eyes of the patient under anesthesia. Furthermore, prone position is not favorable in morbidly obese patients, compromised cardiac index or those with cardiopulmonary diseases (2).

In 1987, PCNL in the supine position was first described by Valdivia et al. (3), aiming to reduce patient-, anesthesia- and surgery-related inconveniences of the prone position, but supine position did not attract much popularity for lots of years to come. Later on, the Valdivia position was improved further by Ibarluzea et al. (4) by adding a modified lithotomy arrangement, giving origin to a new position called Galdakao-modified supine Valdivia position. Supine PCNL gained popularity due to many pros in contrast to prone position in terms of reduced operative time, avoiding injuries resulting from patient repositioning, reduced radiation exposure to surgeon, anesthesia-related complications, and ability of surgeon to perform surgery in sitting position (5). Limited exposure of the flank area for renal puncture is considered to be the major disadvantage of this position. Kumar et al. (6) made some modifications in the supine position resulting in better exposure of flank area. Falahatkar et al. (7) performed the procedure in a complete supine position without using towel roll or changing leg position and found it to be feasible yet safe.

Despite these advantages, the popularity of supine PCNL among urologists worldwide remains modest and is still considered a "new" rather than an alternative position $(8,9)$. Another reason why many experienced surgeons are not very eager to embrace supine position is because they are afraid that this radical change may be cumbersome and may impact surgical outcomes during the learning curve. This is something that an established surgeon does not want to experience (10). Nevertheless, some authors should be congratulated because they confuted this concept, demonstrating that changing position is not cumbersome and the learning curve is rather short, yielding similar or even better outcomes, rather quickly (11).

The importance of this study is to kill the fear factor which resides in minds of many experienced urologists. Hiding behind the false paradigms, which is translated by statements like "supine PCNL is not my thing", the way forward cannot be paved. This study aims to establish safety of supine PCNL, emphasizing the improved efficacy in the process.

\section{Materials and Methods}

This retrospective case-control study was done at the Kidney Centre Postgraduate Training Institute, Karachi, Pakistan. Patients enrolled in the study were those who got operated from October 2017 to May 2018, the reason being that supine PCNL was started at that time in the institute. Prior to performing the study, the ethics committee approval was obtained by the Kidney Centre Ethical Review Committee (date: February 2018, reference number 64-URO-022018).

Fifty patients underwent supine PCNL during the study period (group A). An equal number of patients, who underwent prone PCNL during the same period and bearing similar demographic and clinical attributes, were taken as controls (group B). Therefore, a sample size of 100 was taken consisting of 50 patients as group A and 50 as group B. This was also comparable to the sample size calculated by OpenEpi ${ }^{\mathrm{Tm}}$ sample size calculator by obtaining means and standard deviations of a similar study performed (12).

All adult patients ( $>14$ years), who were electively admitted for PCNL and underwent the procedure in either supine or prone procedure, were analyzed in the study. Demographic details, such as gender and age, and data on body mass index (BMI), 
stone size, stone location and stone laterality were comparable between the two groups. Pre- and post-operative hemoglobin $\mathrm{Hb})$ levels in patients in both groups were also tabulated. Variables analyzed to compare the two groups included operative time, anesthesia time, fall in $\mathrm{Hb}$, blood transfusion, stone clearance and need for auxiliary procedure.

Access acquired with a spinal needle in the prone position was performed using the "triangulation" technique under fluoroscopic guidance, after performing rigid cystoscopy, ureteric catheter placement and retrograde urography in dorsal lithotomy position. Patients, who underwent supine PCNL, had their cystoscopy and ureteric catheter placement also performed in the supine position, instead of dorsal lithotomy position. All procedures were performed by the same urologist. All supine PCNLs were performed in the Valdivia position.

Tract dilatation in both groups was achieved by Alkin's metallic dilators up to $27 \mathrm{Fr}$ and a $30 \mathrm{Fr}$ Amplatz sheath was used. Stone fragmentation was achieved in all patients with pneumatic lithoclast. Nephrostomy tube was not placed in any patient among the two groups. None of the patients required double $J$ stent insertion.

\section{Statistical Analysis}

Normality was checked for all the recorded data. Normally distributed variables were described in terms of mean and standard deviation for continuous variables (age, BMI, residual stone) and parametric testing was performed by the independent samples t-test. Not normally distributed data (stone size, operative time, anesthesia time, pre-operative and post-operative $\mathrm{Hb}$ and fall in $\mathrm{Hb}$ ) was described in terms of median and interquartile ratio (IOR) and was tested using the Mann-Whitney U test. Categorical variables (gender and stone location and laterality) were described in terms of "n number" and were compared between the two groups applying a chisquare test. Data were analyzed using SPSS version 20. A p value of less than 0.05 was taken as statistically significant.

\section{Results}

Forty seven males and 3 females underwent supine PCNL (group A) and 38 males and 12 females underwent prone PCNL (group B) $(p=0.023)$ (Table 1).

There was no significant difference in mean age between patients in group A $(39.52+10.463)$ and group B $(36.66+11.241)$ $(p=0.191)$ (Table 1).

There was no significant difference in mean $\mathrm{BMl}$ in patients in group A $(23.590+4.959)$ was and group B $(24.471+5.400)$ $(p=0.398)$ (Table 1).
The median stone size in patients in group A (2.20; IQR: 1.0), was not significantly different from group $B(2.35 ;$ IQR: 1.1$)$ $(p=1.000)$ (Table 1).

Thirty five patients in group A and 39 in group $B$ had pelvic stone; 15 patients in group $A$ and 11 in group $B$ had lower calyceal stone $(p=0.495)$ (Table 1$)$.

Twenty six patients in group $A$ and 20 in group $B$ had rightsided stone(s); 24 patients in group $A$ and 30 in group B had left-sided stone(s) $(p=0.316)$ (Table 1).

The median operative time in patients in group A (35; IQR: 25) was significantly different from group $B(70 ;$ IOR: 40$)(p=0.000)$ (Table 2).

The median anesthesia time in patients in group A (50; IQR: $25)$ was significantly different from group $B(8 ; 45)(p=0.000)$ (Table 2).

The median pre-operative $\mathrm{Hb}$ in patients in group $\mathrm{A}$ (14.750; IQR: 1.5) was significantly different from group $B(13.900 ; 2.0)$ $(p=0.000)$ (Table 2).

The median post-operative $\mathrm{Hb}$ in patients in group $\mathrm{A}(13.200$; IQR: 1.2), was significantly different from group $B(12.600 ; 3.2)$ $(p=0.000)$ (Table 2).

Table 1. Baseline demographics and clinical characteristics

\begin{tabular}{|c|c|c|c|}
\hline & $\begin{array}{l}\text { Group A } \\
\text { (Supine PCNL) }\end{array}$ & $\begin{array}{l}\text { Group B } \\
\text { (Prone PCNL) }\end{array}$ & \\
\hline & $\begin{array}{l}\text { Number of } \\
\text { patients (n) }\end{array}$ & $\begin{array}{l}\text { Number of } \\
\text { patients }(n)\end{array}$ & p values \\
\hline \multicolumn{4}{|l|}{ Gender } \\
\hline Male & 47 & 38 & \multirow{2}{*}{$p=0.023$} \\
\hline Female & 03 & 12 & \\
\hline \multicolumn{4}{|l|}{ Age (years) } \\
\hline Mean & 39.52 & 36.66 & \multirow{2}{*}{$p=0.191$} \\
\hline Standard deviation & +10.463 & +11.241 & \\
\hline \multicolumn{4}{|l|}{ BMI $\left(\mathrm{kg} / \mathrm{m}^{2}\right)$} \\
\hline Mean & 23.590 & 24.471 & \multirow{2}{*}{$p=0.398$} \\
\hline Standard deviation & +4.959 & +5.400 & \\
\hline \multicolumn{4}{|l|}{ Stone size $(\mathrm{cms})$} \\
\hline Median & 2.20 & 2.35 & \multirow{2}{*}{$p=1.000$} \\
\hline Interquartile range & 1.0 & 1.1 & \\
\hline \multicolumn{4}{|l|}{ Stone location } \\
\hline Pelvis & 35 & 15 & \multirow{2}{*}{$p=0.495$} \\
\hline Lower calyx & 39 & 11 & \\
\hline \multicolumn{4}{|l|}{ Stone laterality } \\
\hline Right side & 26 & 24 & \multirow{2}{*}{$p=0.316$} \\
\hline Left side & 20 & 30 & \\
\hline
\end{tabular}


Table 2. Investigative and operative parameters

\begin{tabular}{|c|c|c|c|}
\hline & $\begin{array}{l}\text { Group A } \\
\text { (Supine PCNL) }\end{array}$ & $\begin{array}{l}\text { Group B } \\
\text { (Prone PCNL) }\end{array}$ & \\
\hline & $\begin{array}{l}\text { Number of } \\
\text { patients (n) }\end{array}$ & $\begin{array}{l}\text { Number of } \\
\text { patients (n) }\end{array}$ & p values \\
\hline \multicolumn{4}{|c|}{ Operative time (minutes) } \\
\hline Median & 35 & 70 & \multirow{2}{*}{$p=0.000$} \\
\hline Interquartile range & 25 & 40 & \\
\hline \multicolumn{4}{|c|}{ Anesthesia time (minutes) } \\
\hline Median & 50 & 85 & \multirow{2}{*}{$p=0.000$} \\
\hline Interquartile range & 25 & 45 & \\
\hline \multicolumn{4}{|c|}{ Pre-operative hemoglobin (gm/dL) } \\
\hline Median & 14.750 & 13.900 & \multirow{2}{*}{$p=0.000$} \\
\hline Interquartile range & 1.5 & 2.0 & \\
\hline \multicolumn{4}{|c|}{ Post-operative hemoglobin (gm/dL) } \\
\hline Median & 13.200 & 12.600 & \multirow{2}{*}{$p=0.000$} \\
\hline Interquartile range & 1.2 & 3.2 & \\
\hline \multicolumn{4}{|c|}{ Fall in hemoglobin (gm/dL) } \\
\hline Median & 1.700 & 1.200 & \multirow{2}{*}{$p=0.967$} \\
\hline Interquartile range & 1.2 & 2.4 & \\
\hline \multicolumn{4}{|l|}{ Blood transfusion } \\
\hline Transfusion done & 02 & 07 & $p=0.080$ \\
\hline \multicolumn{4}{|l|}{ Stone clearance } \\
\hline Complete & 32 & 34 & \multirow{2}{*}{$p=0.833$} \\
\hline Partial & 18 & 16 & \\
\hline \multicolumn{4}{|c|}{ Residual stone size (cms) } \\
\hline Mean & 0.216 & 0.200 & \multirow{2}{*}{$p=0.805$} \\
\hline Standard deviation & +0.324 & +0.322 & \\
\hline \multicolumn{4}{|c|}{ Auxiliary procedure (number of patients) } \\
\hline $\begin{array}{l}\text { Shockwave } \\
\text { lithotripsy }\end{array}$ & 11 & 06 & $p=0.287$ \\
\hline PCNL: Percutaneous neph & ithotomy & & \\
\hline
\end{tabular}

The median fall in $\mathrm{Hb}$ level in patients in group A (1.700; IQR: 1.2) was significantly different from group $B(1.200 ; 2.4)$ $(p=0.967)$ (Table 2).

Two patients in group A and 7 patients in group B needed blood transfusion $(p=0.080)$ (Table 2).

Thirty two patient (64\%) in group A and 34 patients (68\%) in group $B$ achieved complete stone clearance $(p=0.833)$ (Table 2$)$.

There was no significant difference in mean residual stone size between group A $(0.216+0.324)$ and group B $(0.200+0.322)$ $(p=0.805)$ (Table 2).

Eleven patients in group A and 6 patients in group B needed auxiliary procedure in the form of extracorporeal shockwave lithotripsy ( $p=0.287)$ as shown in Table 2.

\section{Discussion}

Prone PCNL has dominated renal stone surgery ventures for the past 3 decades now. After the advent of prone PCNL in the developed world, most of the developing countries have also developed the necessary armamentarium and expertise to acquire this procedure. Since renal stone disease affects a larger chunk of urological patient population, PCNL has become one of the frequently performed procedures in the world. Any renal stone of $>2 \mathrm{~cm}$ should be treated with PCNL wherever available and feasible, according to the recent American and European urology guidelines. With passing time, whilst urologists have developed a stable learning curve for this procedure, new techniques and innovations have revolutionized PCNL procedure vastly. A good example for this notion is the advent of supine PCNL which grants the urologists immunity from adverse effects resulting from previously popular modality of prone PCNL. These adverse effects included changing of patient position causing unnecessary delay, risk of damage to patient's neck, limbs, nerves and eyes; not to forget the least favorable position in morbidly obese patients and those with compromised cardiopulmonary system (2). These outcomes resulted in experimentation of PCNL procedure and thus, supine PCNL was invented by Valdivia back in 1987 (3).

Many trials have demonstrated the benefits of supine PCNL along with its good safety profile. Some of the benefits include reduced operative and anesthesia time and reduced surgeon's fatigue. Falahatkar et al. (7) from Iran conducted a clinical trial on 117 patients who underwent PCNL in the supine position between January 2009 and January 2010. He reported a stone-free rate (SFR) of $77.77 \%$ and also mentioned potential advantages including better urethral access, better control of the airway, less positioning of patients, reduced operative time, a relatively comfortable surgeon, and more rapid access to airway especially in patients with morbid obesity and compromised cardiopulmonary function.

A retrospective study conducted from 2011 to 2016 by Sofer et al. (11) revealed a trend toward shorter operative time (138 vs 150 minutes), anesthesia time (174 vs 192 minutes) and hospitalization (2.2 vs 2.6 days) in the supine PCNL group, without significantly different SFRs as compared to prone PCNL group. The same study also demonstrated that implementation of supine PCNL in their centre reached $96 \%$ in 3 years. The reason was that both anesthesiologists and urologists expressed their unanimous preference for supine position over the prone one.

Another retrospective study by Sohail et al. (12) conducted from January 2011 to December 2015 on 197 patients showed that the mean operative time in supine PCNL was $32.3+6.6 \mathrm{~min}$ shorter than that in the prone position $(\mathrm{p}<0.001)$. They also 
noted that the mean hospital stay was $1.2+0.75$ days shorter for the supine vs the prone position $(p<0.001)$.

Abdel-Mohsen et al. (13) conducted a prospective study from October 2008 to March 2010 in Zagazig University, Egypt, in which 77 patients with renal stones were randomized into two groups: group A (39 patients) were operated using the freeflank modified supine position, and group B (38 patients) in the prone position; SFR, operative time and complication rates were compared. The results revealed that SFRs were $84.6 \%$ and $84 \%$ in group $A$ and $B$, respectively. Furthermore, operative time was significantly longer in group B (prone) than in A (freeflank modified supine) and there was no significant difference between the groups in terms of complications.

Our study demonstrated comparable results with the aforementioned literature in many ways. Operative as well as anesthesia times were significantly reduced in patients undergoing supine PCNL whereas there was no difference in stone clearance rate between supine (64\%) and prone (68\%) PCNL cases.

\section{Study Limitations}

The prominent limitation of the study is its retrospective nature and future prospective trials would be more beneficial in establishing stronger evidence. Another limitation of the study is its small sample size which can be addressed after further prospective trials in the future. Another limitation could be the use of only single type of supine position (Valdivia) and this limitation can be tackled by experimenting on Galdakao (modified Valdivia) position in future trials.

\section{Conclusion}

Supine PCNL is as safe and effective as the conventionally performed prone PCNL, but with an added benefit of decreased operative and anesthesia time due to nullification of changing of patient's position during the procedure. Furthermore, the surgeon's as well as anesthetist's comfort associated with supine position is a contrasting advantage in the scope of ergonomics during this very common urological procedure.

\section{Acknowledgments}

First and foremost I am highly grateful to almighty ALLAH, the most gracious and the most merciful, who bestowed upon me health, wisdom, knowledge and power of communication. He granted me the serenity to accept the things I cannot change; courage to change the things I can; and wisdom to know the difference.

I owe a great deal to my supervisor for valuable guidance, encouragement and supervision which made it possible for me to undertake this project and complete my training in this specialty.

I am deeply in debt for support of my colleagues, whether seniors or juniors, whose co-operation proved very helpful in compilation of my manuscript.

I am also gratified to put word of thanks for my parents and my beloved wife for their motivation, co-operation \& affection in helping me tide over my difficulties and enabling me to do my postgraduate training and to complete this research work.

Last but not the least; I would love to mention a very dear colleagues (Ms. Naela Umer, Mr. Anees Badar Soomro \& Ms. Khatija Moiz) who helped with immense tabulation of work and other logistics during this research.

Primary investigator or patients did not have any conflict of interest. Institutional grant was approved and used for the extra routine investigations.

\section{Ethics}

Ethics Committee Approval: This study was approved by the Kidney Centre Ethical Review Committee (date: February 2018 , reference number 64-URO-022018).

Informed Consent: Not applicable because this was a retrospective study of patients' clinical and surgical records.

Peer-review: Externally peer-reviewed.

\section{Authorship Contributions}

Surgical and Medical Practices: A.S.A., S.E.K., S.A.K., S.M., Concept: A.S.A., Design: A.S.A., Data Collection or Processing: A.S.A., S.A.K., J.S., I.S., Analysis or Interpretation: A.S.A., Literature Search: A.S.A., Writing: A.S.A.

Conflict of Interest: No conflict of interest was declared by the authors.

Financial Disclosure: The authors declared that this study received no financial support.

\section{References}

1. Fernström I, Johansson B. Percutaneous pyelolithotomy. A new extraction technique. Scad J Urol Nephrol 1976;10:257-259.

2. Atkinson CJ, Turney BW, Noble JG, Reynard JM, Stoneham MD. Supine vs prone percutaneous nephrolithotomy: an anesthetist's view. BJU Int 2011;108:306-308.

3. Valdivia Uria JG, Valle Gerhold J, López López JA, Villarroya Rodriguez S Ambroj Navarro C, Ramirez Fabián M, Rodriguez Bazalo JM, Sánchez Elipe MA. Technique and complications of percutaneous nephroscopy: experience with 557 patients in the supine position. J Urol 1998;160:1975-1978.

4. Ibarluzea G, Scoffone CM, Cracco CM, Poggio M, Porpiglia F, Terrone C Astobieta A, Camargo I, Gamarra M, Tempia A, Valdivia Uria JG, Scarpa RM. Supine Valdivia and modified lithotomy position for simultaneous anterograde and retrograde endourological access. BJU Int 2007;100:233-236. 
5. Hoznek A, Rode J, Ouzaid I, Faraj B, Kimuli M, de la Taille A, Salomon L, Abbou CC. Modified supine percutaneous nephrolithotomy for large kidney and ureteral stones: technique and results. Eur Urol 2012;61:164-170.

6. Kumar P, Bach C, Kacrillas S, Papatsoris AG, Buchholz N, Masood J. Supine percutaneous nephrolithotomy (PCNL): 'in vogue' but in which position? BJU Int 2012;110:1018-1021.

7. Falahatkar S, Farzan A, Allahkhah A. Is complete supine percutaneous nephrolithotripsy feasible in all patients? Urol Res 2011;39:99-104.

8. Ghani KR, Andonian S, Bultitude M, Desai M, Giusti G, Okhunov Z, Preminger GM, de la Rosette J. Percutaneous nephrolithotomy: Update, trends, and future directions. Eur Urol 2016;70:382-396.

9. Valdivia JG, Scarpa RM, Duvdevani M, Gross AJ, Nadler RB, Nutahara K, de la Rosette JJ; Croes PCNL Study Group. CROES PCNL Study Group. Supine versus prone position during percutaneous nephrolithotomy: a report from the clinical research office of the endourological society percutaneous nephrolithotomy global study. J Endourol 2011;25:1619-1625.

10. Giusti G, Proietti S. Supine PCNL is the way to go! Central European J Urol 2017;70:66-67.

11. Sofer M, Tavdi E, Levi O, Mintz I, Bar-Yosef Y, Sidi A, Matzkin H, Tsivian A. Implementation of supine percutaneous nephrolithotomy: a novel position for an old operation. Cent European J Urol 2017;70:60-65.

12. Sohail N, Albodour A, Abdelrahman KM. Percutaneous nephrolithotomy in complete supine flank-free position in comparison to prone position: A single-centre experience. Arab J Urol 2017; 15:42-47.

13. Abdel-Mohsen E, Kamel M, Zayed AL, Salem EA, Ebrahim E, Wahab KA, Elaymen A, Shaheen A, Kamel HM. Free-flank modified supine vs. prone position in percutaneous nephrolithotomy: A prospective randomised trial. Arab J Urol 2013;11:74-78. 